\title{
“PEJOTIZAÇÃO”: PRECARIZAÇÃO DAS RELAÇÕES DE TRABALHO, DAS RELAÇÕES SOCIAIS E DAS RELAÇÕES HUMANAS
}

\author{
“PEJOTIZAÇÃO”: PRECARIOUS LABOR RELATIONS, SOCIAL RELATIONS \\ AND HUMAN RELATIONS
}

\begin{abstract}
AtTILA MAGno e Silva Barbosa
Doutor em Sociologia pela Universidade Federal de São Carlos (2010), mestre em Antropologia Social pela Universidade Federal do Pará (2000), bacharel em Direito pela Universidade da Amazônia (2001) e Bacharel em Ciências Sociais pela Universidade da Amazônia (1995). Professor Adjunto II do Instituto de Filosofia, Sociologia e Política e do Programa de Pós-graduação em Sociologia da Universidade Federal de Pelotas - UFPel barbosaattila@uol.com.br

JuLIANI VeroneZI ORBEM Mestre em Sociologia pela Universidade Federal de Pelotas (2015), especialista em Direito do Trabalho e Processo do Trabalho pela Faculdade de Direito Damásio de Jesus (2013) e bacharel em Direito pela Universidade Federal de Pelotas (2012). Advogada trabalhista juorbem@gmail.com
\end{abstract}

\section{RESUMO}

A relação de emprego confere ao trabalhador a proteção do Direito do Trabalho e um conjunto de direitos sociais trabalhistas que the possibilita a sua subsistência diária como, também, a subvenção extratrabalho. No entanto, a "pejotização", prática fraudulenta, que utiliza de um contrato de prestação de serviços para camuflar a relação de emprego, exclui o trabalhador desse âmbito de proteção conferido pelo Direito do Trabalho, acarretando precarização das relações de trabalho, das relações sociais e das relações humanas. Assim, o presente artigo visa discutir o fenômeno da "pejotização" e quais as consequências sociais e jurídicas deletérias causadas por este instituto. No referente à metodologia optou-se pelo método de abordagem indutivo e como método de procedimento o monográfico, utilizando como técnica de coleta de dados a pesquisa bibliográfica e jurisprudencial.

Palavras-chave: Consequências sociais e jurídicas deletérias; "Pejotização"; Precarização; Relação de emprego.

\begin{abstract}
The employment relationship gives the employee the protection of Labor Law and set of social labor rights that provides you from your daily living as well as grant beyond work. However, the "pejotização", fraudulent practice, which uses a contract to provide services to disguise the employment relationship, the employee excludes this scope of protection conferred by the Labor Law, resulting precarious of labor relations, social relations and human relations. Thus, this article aims to discuss the phenomenon of "pejotização" and what the social and legal consequences deleterious caused by this institute. With regard to methodology we opted for the inductive approach method and procedure as the monographic method, using as technique of the data collection the bibliographical research and case law.
\end{abstract}

Keywords: Social and legal deleterious consequences; "Pejotização"; Precarious; Employment relationship. 


\section{SUMÁRIO}

INTRODUÇAO; 1 A RELAÇÃO CONTRATUAL DENOMINADA "PEJOTIZAÇÃO"; 2 A VIABILIDADE LEGAL DA "PEJOTIZAÇÃO"; 3 EFEITOS SOCIAS E JURÍDICOS DELETÉRIOS DA "PEJOTIZAÇÃO"; 4 EFEITOS SOBRE 0 CONTRATO DE EMPREGO E O SUJEITO DE DIREITO EMPREGADO; CONCLUSÃO; REFERÊNCIAS.

\section{INTRODUÇÃO}

A temática do presente trabalho volta-se para a análise de uma modalidade de externalização das atividades denominada "pejotização". Uma relação de trabalho na qual o trabalhador, pessoa física, para ser contratado ou para manter o posto de trabalho em determinada empresa necessita constituir uma pessoa jurídica, que pode ser uma firma individual ou uma sociedade empresária. Deste modo, haverá uma relação interempresarial, regulada pelo Direito Civil, na qual o trabalhador irá prestar os serviços na empresa contratante através de um contrato de prestação de serviços concretizado entre a empresa contratante e a pessoa jurídica do trabalhador, não havendo a incidência de qualquer direito trabalhista.

Para parcela da doutrina trabalhista a “pejotização" possui viabilidade legal, estando amparada pela Lei $n^{\circ} 11.196 / 2005$, Lei do Bem, sendo uma relação trabalhista lícita. No entanto, para parcela da doutrina trabalhista, majoritária, tal prática trata-se de uma fraude à legislação trabalhista, previdenciária e fiscal, pois camufla a verdadeira relação existente, a relação de emprego.

Assim, a problemática central a ser discutida refere-se ao seguinte questionamento: Quais as consequências a "pejotização" desponta sobre as relações de trabalho, as relações sociais e as relações humanas?

A hipótese construída pretende oferecer alguns elementos jurídicos que permitam compreender o fenômeno da "pejotização" no contexto trabalhista brasileiro a partir da doutrina e da jurisprudência e suas implicações sociais e jurídicas. ${ }^{1}$

Em relação aos aspectos metodológicos da pesquisa optou-se pelo método de abordagem indutivo, pelo método de procedimento monográfico, utilizando como técnica de coleta de dados a pesquisa bibliográfica e jurisprudencial. Com relação à análise de jurisprudências foram

${ }^{1} \mathrm{O}$ artigo é parte da dissertação de mestrado em Ciências Sociais, que teve como temática a "pejotização", apresentada no programa de Pós-Graduação em Sociologia da Universidade Federal de *** ***. 
examinados 70 (setenta) acórdãos do Tribunal Superior do Trabalho - TST, relativos ao período de 01/01/2008 até abril de 2014 e 53 (cinquenta e três) acórdãos do Tribunal Regional do Trabalho da $4^{\mathrm{a}}$ Região - TRT da $4^{\mathrm{a}}$ Região/RS, correspondentes ao período de 01/01/2011 a 15/07/2014, ligados à temática da “pejotização” e que serviram para demonstrar no texto o entendimento da Justiça do Trabalho a respeito de tal fenômeno.

0 trabalho está estruturado em quatro seções. Na primeira parte aborda-se sobre a modalidade de externalização das atividades denominada "pejotização". Na segunda seção discute-se sobre a viabilidade legal dessa relação trabalhista. No terceiro item analisa-se quais os efeitos sociais e jurídicos deletérios causados pela “pejotização" que são apontados pela doutrina e pela jurisprudência trabalhista. E, por fim, na quarta seção examina-se quais os efeitos que a "pejotização" causa sobre o contrato de emprego e o sujeito de direito emprego.

\section{A RELAÇÃO CONTRATUAL DENOMINADA “PEJOTIZAÇÃO”}

As relações de trabalho tornam-se cada vez mais multiformes em suas possibilidades jurídicas e nos arredores da relação de emprego assalariado emergem outras formas de contratação de contornos mais flexíveis. São as chamadas "novas" ou "atípicas" formas de trabalho como, por exemplo, o trabalho temporário, o trabalho a tempo parcial, a terceirização, os cooperados, os estágios, os falsos autônomos, os contratos como pessoa jurídica, dentre outros. $^{2}$

Os contratos atípicos só podem ser definidos com base no modelo de contrato típico. E no Direito do Trabalho brasileiro o contrato legal e socialmente típico é a relação de emprego definida pela CLT como a relação de trabalho prestada por pessoa física, de maneira pessoal, não eventual, com onerosidade e subordinação.

De forma geral, os contratos atípicos são os contratos que não possuem reconhecimento legal trabalhista, como a “pejotização”, portanto, não havendo a incidência de direitos laborais; ou que possuem reconhecimento legal, sendo contratos de trabalho formais, como o trabalho temporário, o trabalho a tempo parcial, a terceirização, os cooperados, os estágios, havendo a regulação pelo Estado que determina apenas algumas poucas obrigações aos contratantes no que diz respeito aos encargos sociais e direitos trabalhistas quando comparados ao contrato típico.

\footnotetext{
${ }^{2}$ CARELLI, Rodrigo de Lacerda. Formas atípicas de trabalho. 2. ed. São Paulo: LTr, 2010, p. 16.
} 
Para Reimann os contratos "atípicos" são criados como alternativa para a contratação tradicional do trabalho, com a pretensão de atender às demandas do mercado de trabalho em função da reestruturação produtiva. E com a crise econômica e o crescente desemprego passam a adquirir relevância como modelo de ocupação e de trabalho remunerado. Estes são, via de regra, contratos que causam alterações no tempo de duração da relação, seja diária, semanal ou mensal e também no grau de subordinação entre empregados e empregadores. ${ }^{3}$

Reimann coloca que "a relação típica de trabalho, do futuro, tende a ser aquela que hoje denominamos atípica". " Uma dessas formas "atípicas" de trabalho, objeto dessa pesquisa, é a “pejotização", modalidade de externalização ${ }^{5}$ da mão de obra, que a cada dia vem ganhando mais espaço no cenário nacional.

A “pejotização" pode ser caracterizada como uma forma de contratação na qual a empresa contratante para a efetivação da contratação ou para a manutenção do posto de trabalho exige que o trabalhador, pessoa física, constitua uma pessoa jurídica, que pode ser uma firma individual ou uma sociedade empresária, para a prestação de serviços de natureza personalíssima. Assim, realiza-se um contrato de prestação de serviços de natureza civil para a execução das atividades, sendo tal modalidade de contratação regulamentada, então, pelo Direito Civil e não pelo Direito do Trabalho.

Logo, esse prestador de serviços seria um trabalhador parassubordinado ${ }^{6}$, um colaborador, detentor de maior autonomia, que estaria inserido na estrutura da empresa contratante prestando uma colaboração continuada e coordenada. A ideia do trabalhador parassubordinado remete a ideia de alguém que não recebe comando, que dirige a sua atividade, que deixou a subordinação para trás e que agora é um empresário.

\footnotetext{
3 REIMANN, Marcos Francisco. Cidadania e contratos atípicos de trabalho: as políticas sociais e o ordenamento do trabalho. Porto Alegre: Fabris, 2002, p. 144.

${ }^{4}$ REIMANN, Marcos Francisco. Cidadania e contratos atípicos de trabalho: as políticas sociais e o ordenamento do trabalho. Porto Alegre: Fabris, 2002, p. 43.

${ }^{5}$ A externalização/terceirização é um processo que visa transferir atividades secundárias da empresa, passando esta a se concentrar na sua atividade principal, para que outra empresa ou terceiro as executem. Conforme Ramos Filho (2012, p. 284) o significante externalização/terceirização comporta vários processos como a prática da contratação terceirizada, da "pejotização" e da subordinação do consumidor.

${ }^{6}$ Segundo Nascimento (2011) a figura da parassubordinação foi criada na Itália no final da década de 1950 para se reportar a uma terceira categoria de trabalho intermediária entre o trabalho autônomo e o subordinado. Assim, de acordo com a teoria italiana o trabalhador parassubordinado é aquele que trabalha com pessoalidade, de forma continua, com colaboração e coordenação, estando inserido na estrutura organizacional da empresa, não sendo subordinado e sim detentor de certa autonomia, o que faz com este não se enquadre na relação de emprego clássica, sendo visto como um colaborador da empresa contratante. Essa terminologia também pode ser encontrada em outros países como na Alemanha, França e Espanha.
} 
Salienta-se que a “pejotização" e a terceirização são institutos diferentes, que se assemelham apenas por se trataram de modalidades de externalização, na qual a empresa contratante repassa para terceiros a execução de determinadas atividades. Enquanto na terceirização existe uma relação triangular entre a empresa contratante, a empresa interposta, tomadora ou terceirizada, e o trabalhador terceirizado, na qual a empresa principal transfere parte de suas atividades, as não essenciais, para que empregados de uma empresa terceirizada os executem; na "pejotização" há uma relação bilateral, na qual uma empresa contrata uma pessoa física, que prestará serviços de forma pessoal, sob a forma de uma pessoa jurídica.

Para se transformar em "pejota” a pessoa deve, então, constituir uma pessoa jurídica, obtendo um número de CNPJ- Cadastro Nacional da Pessoa Jurídica - que the confere uma identidade/personalidade jurídica. Assim, passa a prestar serviços como trabalhador autônomo regulamentado como Microempreendedor Individual - $\mathrm{MEI}$, sendo identificado pelo número do CNPJ - Cadastro Nacional da Pessoa Jurídica, passando a emitir nota fiscal e não mais RPA Recibo de Pagamento a Autônomo.

Para a empresa que contrata um "pejota” não haverá pagamento dos encargos trabalhistas e fiscais, passando a usufruir de uma carga tributária reduzida, além de contar com uma prestação de serviço ininterrupta pelos 12 (doze) meses do ano, já que a empresa contratada não tem direito ao gozo de férias. Desta forma, estará liberada do pagamento da contribuição de $20 \%$ para o INSS sobre a folha, da contribuição para o Sistema "S" sobre este prestador de serviços, não precisará pagar a alíquota de $8 \%$ referente ao FGTS - Fundo de Garantia Por Tempo de Serviço, nem a indenização de $40 \%$ sobre o total dos valores depositados em caso de rescisão contratual, como também estará livre do aviso-prévio proporcional ao tempo de serviço e, por fim, como não há pagamento de salário não estará obrigada a efetuar o reajuste salarial na data base. Por conseguinte, ao deixar de utilizar uma relação de trabalho para usar uma relação comercial a empresa contratante reduz custos com suas operações, visto que tal modalidade de contratação não aparecerá mais no setor de recursos humanos, mas sim no setor de compras da empresa.

A pessoa contratada como "pejota" vende sua força de trabalho como empresário ou trabalhador autônomo, transparecendo "suposta" autonomia na execução das atividades. Deste modo, esta pagará imposto de renda como pessoa jurídica e não como pessoa física e fará recolhimentos dos encargos sociais como empresário. O que torna tal situação atrativa para muitos trabalhadores é a possibilidade do trabalho prestado com autonomia, a possibilidade de um ganho maior e de maior desconto com as despesas, já que, por exemplo, os encargos sociais 
a serem recolhidos como empresário são menores quando comparados ao de um trabalhador formal. No entanto, o trabalhador “pejotizado" abrirá mão dos direitos trabalhistas, arcando com os custos de manutenção da pessoa jurídica como, por exemplo, com a emissão de notas fiscais, a administração contábil, o pagamento de impostos, o planejamento de reservas, assumindo todos os riscos da atividade econômica.

No entanto, a Justiça do Trabalho, muitos doutrinadores justrabalhistas e de outras áreas compreendem a "pejotização" como uma prática fraudulenta, que utiliza a contratação de uma pessoa jurídica para camuflar a relação de emprego, fraudando, assim, a legislação trabalhista, previdenciária e fiscal. Desta maneira, haveria a transformação do trabalhador empregado, pessoa física, em prestador de serviços por intermédio da constituição de uma pessoa jurídica para que não haja a incidência de qualquer direito social trabalhista.

Thébaud-Mony e Druck em estudo sobre a terceirização/subcontratação no Brasil e na França apontam que este é um fenômeno velho e novo, velho porque a subcontratação é uma prática que historicamente se faz presente desde as fases iniciais de consolidação do modo de produção capitalista, vide o putting out system ${ }^{7}$, e novo porque acaba incitando a emergência de novas modalidades. As autoras apontam que nos últimos 15 (quinze) anos houve grande crescimento da terceirização/subcontratação em todas as direções, ocorrendo à expansão de novas modalidades. Dentre estas destacam como uma das principais, que vem sendo utilizado tanto no setor público como no privado, a contratação de empresas individuais, que são em geral incentivadas pela lógica do empreendedorismo. Tal modalidade se pauta pelo discurso da liberdade das empresas em se desobrigar dos compromissos de gestão do trabalho, dos encargos e direitos sociais trabalhistas, forçando o trabalhador a constituir uma pessoa jurídica, registrando-a em seu nome, alterando assim sua personalidade jurídica. Esta situação transforma o assalariado em empresário, fazendo-o perder todos os direitos trabalhistas, visto que o contrato agora se dá entre empresas, sendo regido pelo direito comercial, relação na qual prevalece a igualdade entre as partes. ${ }^{8}$

\footnotetext{
${ }^{7}$ Corresponde à distribuição dos materiais na base da empreitada aos trabalhadores, para a manufatura em suas casas, por meio de subcontratadores e agentes de comissão.

8 THÉBAUD-MONY, Annie; DRUCK, Graça. Terceirização: a erosão dos direitos dos trabalhadores na França e no Brasil. In: A perda da razão social do trabalho: terceirização e precarização. São Paulo: Boitempo, 2007, p. 46.
} 
Ramos Filho destaca entre os inúmeros processos de externalização a terceirização, o mais conhecido deles, a "pejotização" e a subordinação do consumidor'. As duas primeiras são modalidades de externalização, mas não se confundem, pois, enquanto na terceirização parte das atividades da empresa são transferidas para que empregados de uma empresa terceirizada os executem a um custo menor para a empresa contratante, na “pejotização" a empresa contratada é uma pessoa física sob a forma de pessoa jurídica para que esta preste serviço de forma pessoal, “em condições análogas às dos empregados, geralmente em fraude ao que dispõe o Direito Capitalista do Trabalho". ${ }^{10}$

Como ainda não existem dados na literatura jurídica que identifiquem o ano que a “pejotização" começou a ser usada no Brasil buscou-se analisar nos 123 (cento e vinte três) acórdãos do Tribunal Superior do Trabalho - TST e do Tribunal Regional do Trabalho da $4^{\text {a }}$ Região - TRT da $4^{a}$ Região/RS quais as datas dos contratos de “pejotização". Nesse sentido, pode-se extrair como referente empírico que já nas décadas de 1990, com contratos iniciados em 1993, 1996 e 1998 e posteriormente em maior quantidade no ano 2000, a “pejotização” se fazia presente no cenário nacional.

Todavia, essa prática pode ser mais antiga conforme relata a desembargadora Maria Adnar Aguiar, do Tribunal Regional do Trabalho da $5^{\text {a }}$ Região/Bahia - TRT da $5^{\text {a }}$ Região/BA, em processo de 2004, julgado pelo Tribunal em 2009, no qual um advogado havia trabalhado para uma empresa como empregado de dezembro de 1983 a dezembro de 1986, ocasião em que foi demitido e recontratado como prestador de serviços:

\begin{abstract}
O fenômeno ocorrido nos presentes autos embora incipiente em 1986, ganhou depois grande notoriedade no mundo das relações de trabalho e é hoje denominado de pejotização. A pejotização é uma forma de terceirização mediante a qual a mesma pessoa, antes empregada, continua a realizar os mesmos serviços com a diferença de que a forma do contrato de trabalho transmuda-se geralmente sob a denominação jurídica de profissional liberal, micro-empresa ou cooperativa. ${ }^{11}$
\end{abstract}

\footnotetext{
${ }^{9}$ Segundo Ramos Filho (2012, p. 284) é um processo complexo no qual uma parte do trabalho, executada anteriormente por um empregado da empresa, é transferido ou externalizado, fazendo com que o próprio consumidor final do bem ou serviço execute o trabalho para a empresa, porém de forma não remunerada, aumentando, assim, sua margem de lucro e sua produtividade.

${ }_{10}$ RAMOS FILHO, Wilson. Direito capitalista do trabalho: história, mitos e perspectivas no Brasil. São Paulo: LTr, 2012, p. 284.

${ }^{11}$ BRASIL. Tribunal Regional do Trabalho ( $5^{a}$ Região/BH). Acórdão de decisão que negou provimento a preliminar de nulidade de sentença por ausência de completa prestação jurisdicional e, no mérito, concedeu provimento parcial ao recurso do reclamado quanto à prescrição do FGTS, e também provimento parcial ao recurso do reclamante enquadrando-o na categoria de bancário. Recurso ordinário $\mathrm{n}^{\circ}$ 0049200-11.2004.5.05.0021. Jeferson Malta de Andrade e Banco HSBC. Relator:
} 
Essa modalidade de contratação passou a ser identificada por diversas denominações: contratação entre empresas; interposição de empresas; empresa do "eu sozinho", porque o serviço é prestado com exclusividade por uma pessoa; “pejutização”; e, ainda, "PJs”. Porém, devido a sua prática reiterada tal fenômeno passou a ser designado pelos juristas e doutrinadores trabalhistas brasileiros pelo neologismo "pejotização", pois para se reportar a terminologia pessoa jurídica comumente utiliza-se a sigla PJ, assim, os trabalhadores que constituíam uma pessoa jurídica para prestação de serviços estavam sendo caracterizados pela abreviação PJ - “pejota”. Portanto, foram os chamados "pejotas” que inspiraram a criação do termo “pejotização”, isto é, da subjetivação da sigla PJ formulou-se o respectivo neologismo.

\section{A VIABILIDADE LEGAL DA “PEJOTIZAÇÃO”}

A prática da "pejotização" ganhou ares de legalidade com a edição da Lei $\mathrm{n}^{\circ}$ 11.196/2005, Lei do Bem, prevendo seu artigo 129:

Para fins fiscais e previdenciários, a prestação de serviços intelectuais, inclusive os de natureza científica, artística ou cultural, em caráter personalíssimo ou não, com ou sem a designação de quaisquer obrigações a sócios ou empregados da sociedade prestadora de serviços, quando por esta realizada, se sujeita tãosomente à legislação aplicável às pessoas jurídicas, sem prejuízo da observância do disposto no art. 50 da Lei no 10.406 , de 10 de janeiro de 2002 - Código Civil. ${ }^{12}$

Assim, o art. 129, da referida Lei, autoriza a contratação de trabalhadores para a prestação de serviços intelectuais através de pessoa jurídica, servindo, também, como incentivo fiscal tanto para os trabalhadores como para os contratantes.

Desembargadora Maria Adna Aguiar. 19 de novembro de 2009. Disponível em: <http://www.trt5.jus.br/jurisprudencia/modelo/AcordaoConsultaBlob.asp?v_id=173584>. Acesso em: 12 mar. 2015, grifo nosso.

12 BRASIL. Lei $n^{\circ} 11.196$, de 21 de novembro de 2005. Institui o regime especial de tributação para a plataforma de exportação de serviços de tecnologia da informação - REPES, o regime Especial de aquisição de bens de capital para empresas exportadoras - RECAP e o programa de inclusão digital; dispõe sobre incentivos fiscais para a inovação tecnológica; e dá outras providências. . In: Diário Oficial da República Federativa do Brasil, Brasília, DF, 21 nov. 2005. Disponível em: <http://www.planalto.gov.br/ccivil_03/_ato2004-2006/2005/lei/l11196.htm>. Acesso em: 15 jan. 2015. 
Com base neste artigo os defensores da "pejotização", como relação de trabalho lícita, passaram a justificar que os incentivos nele contidos conferem ao trabalhador e ao empresário a opção de escolha do modo empresarial de vinculação na prestação de serviços intelectuais em detrimento à legislação trabalhista, pois haveria a compensação pelos benefícios fiscais e previdenciários. Logo, trata-se de possibilidade de contratação legalmente autorizada, que ressalta os princípios da livre iniciativa, auto-organização e liberdade de contratação.

Diante da previsão legal, empregadores passaram a contratar cada vez mais "pejotas" para a prestação de serviços intelectuais e também trabalhadores submetidos a outras atividades. Essa expansão para outras áreas além da intelectual é amparada pelo art. $7^{\circ}$, XXXII, da Constituição de 1988 e pelo parágrafo único do art. $3^{\circ}$, da CLT, os quais mencionam que não deve haver distinção entre o trabalho intelectual, técnico e manual.

Portanto, os defensores da "pejotização", como relação trabalhista lícita, alegam que a referida lei trouxe a possibilidade de opção para os trabalhadores se transformarem em pessoas jurídicas, abdicando da condição de empregado. Tais proferem o entendimento de que a lei estaria disponibilizando, conforme critérios de conveniência e oportunidade, aos agentes sociais envolvidos na prestação de qualquer modalidade de serviço a livre escolha da espécie de relação que irão pactuar. Desta maneira, por sua livre iniciativa e vontade o trabalhador pode optar pela condição de prestador de serviços. Nessa corrente que defende a "pejotização”, como relação de trabalho lícita, estão juristas trabalhistas como Pereira e Robortella.

Pereira é favorável a tal modalidade de contratação para professores de cursos preparatórios para Exame da Ordem dos Advogados do Brasil - OAB e para concursos públicos. Tais trabalhadores acabam aderindo a “pejotização", pois a tributação que recai sobre o trabalho autônomo é maior do que a que recaí sobre uma pessoa jurídica, normalmente inserida no SIMPLES ${ }^{13}$. Defende, então, a necessidade de uma "proteção temperada, mitigada ou relativizada" para esses trabalhadores, com a criação de uma "Lei do Trabalhador Pejotizado" ou "Lei da Pejotização”. Deste modo, a lei que regulamentará a “pejotização” deverá estabelecer as possibilidades lícitas e os direitos trabalhistas que farão jus tais trabalhadores. ${ }^{14}$

O referido autor ainda alerta que a proibição de tal fenômeno representará aumento considerável do trabalho informal. E no vértice oposto, com a sua regulamentação haverá o

\footnotetext{
${ }^{13}$ O Simples Nacional é um regime compartilhado de arrecadação, cobrança e fiscalização de tributos aplicável às Microempresas e Empresas de Pequeno Porte, previsto na Lei Complementar $n^{\circ} 123$, de 14 de dezembro de 2006.

${ }^{14}$ PEREIRA, Leone. Pejotização: o trabalhador como pessoa jurídica. São Paulo: Saraiva, 2013.
} 
aumento do trabalho regular, com uma proteção do Direito do Trabalho, embora mitigada, ampliando, assim, o número de oferta de trabalho e de arrecadação para os cofres públicos. ${ }^{15}$

Robortella é partidário da utilização de contratos de natureza civil, como a “pejotização", para trabalhadores de alta qualificação, pois no seu modo de entender, o trabalhador com formação sofisticada e o jovem com elevado espírito empreendedor não se sentem mais confortáveis com os limites da relação de emprego. 0 autor defende que os profissionais de extrema especialização e conhecimento não podem ser submetidos à homogeneidade da legislação trabalhista, sendo caracterizados como empregados, já que quando no livre exercício da autonomia da vontade voltam-se para o trabalho em regime de autônomo ou com a constituição de empresas prestadoras de serviços. ${ }^{16}$

Assim, o autor considera um avanço a Lei $n^{\circ} 11.196 / 2005$ ao dispor sobre a contratação de pessoas jurídicas em certas atividades, já que é perfeitamente aceitável a diferença de tratamento jurídico e nível de proteção para as diversas formas de inserção no mercado de trabalho. Tal legislação trouxe razoável segurança jurídica às novas formas de contratação de prestação de serviços, como as que ocorrem por meio de pessoa jurídica e que não necessitam da tutela da legislação trabalhista. Então, deve-se respeitar a liberdade de iniciativa de contratar dos trabalhadores de alta qualificação, para, desta forma, imprimir segurança jurídica aos contratos e as vontades das partes, como pressuposto para o desenvolvimento social e econômico. ${ }^{17}$

No entanto, cabe ressaltar que a Lei $n^{\circ} 11.196 / 2005$ é uma Lei de cunho tributário e não trabalhista. E caso a pessoa se encaixe na modalidade de prestação de serviços prevista na referida Lei, sendo verdadeiramente uma pessoa jurídica, usufruirá dos incentivos fiscais e previdenciários conferidos pela Lei $\mathrm{n}^{\circ} 11.196 / 2005$, passando a ser regida, então, pelo regramento civil, sem a incidência de qualquer norma trabalhista. Portanto, ao se tratar de contrato civil, tendo suas cláusulas contratuais respeitadas conforme a legislação própria, com total autonomia, liberdade e capacidade organizativa do prestador de serviços, não se irá extrair a relação de emprego.

\footnotetext{
${ }^{15}$ PEREIRA, Leone. Pejotização: o trabalhador como pessoa jurídica. São Paulo: Saraiva, 2013.

${ }^{16}$ ROBORTELLA, Luiz Carlos Amorim. O novo conceito de proteção no direito do trabalho. Temas do Direito do Trabalho e Seguridade Social: homenagem ao professor Cássio Mesquita Barros. São Paulo: LTr, 2013.

17 ROBORTELLA, Luiz Carlos Amorim. O novo conceito de proteção no direito do trabalho. Temas do Direito do Trabalho e Seguridade Social: homenagem ao professor Cássio Mesquita Barros. São Paulo: LTr, 2013.
} 
Todavia, no contexto do Direito do Trabalho a "pejotização" ainda não dispõe de viabilidade legal como forma de trabalho regulamentado por lei trabalhista, não havendo a incidência de qualquer direito juslaboral. Nesse sentido, essa modalidade de contratação vem sendo amplamente debatida em âmbito judicial trabalhista, com a resolução da questão caso a caso, conforme o contexto de prova produzido, o convencimento e a compreensão desse fenômeno e dos elementos ligados a ele, a relação de trabalho autônomo e de emprego, pelo magistrado trabalhista.

Portanto, na Justiça do Trabalho a discussão acerca da “pejotização" traz a defrontação de dois institutos jurídicos tradicionais: por um lado o emprego assalariado protegido pelo direito trabalhista, com a prevalência da figura do trabalhador hipossuficiente e, por outro, o trabalho autônomo, relação regulada pelo Direito Civil, em que há uma igualdade entre os dois contratantes.

Das jurisprudências analisadas sobre a “pejotização" observou-se que a Justiça do Trabalho tem demonstrado que a utilização da empresa interposta individual tem servido para mascarar a relação de emprego. A empresa é constituída de fachada, na modalidade individual ou sociedade limitada, situação que os sócios aparecem como meros figurantes da relação, sendo por vezes a mãe, a esposa, o marido ou algum parente, para que o "véu" da formalidade afaste o estatuto salarial. Verifica-se que o trabalhador “pejota” é inserido no processo produtivo da atividade econômica da empresa contratante, desempenhando atividades imprescindíveis à consecução do empreendimento empresarial.

À vista disso, a Justiça do Trabalho tem comprovado que a contratação de uma pessoa jurídica para prestação de serviços personalíssimos vem sendo usada para substituir o contrato de emprego, na tentativa de descaracterizar o vínculo de emprego, através da utilização de um contrato de prestação de serviços de natureza civil. Por tal razão, entende como "pejotização" apenas quando a prática está ligada a uma conotação negativa, isto é, só compreende como “pejotização” quando a pessoa jurídica é usada para mascarar a relação de emprego, fraudando a legislação trabalhista, previdenciária e fiscal.

Por tal razão, quando o Judiciário Trabalhista detecta que naquele caso havia uma empresa que foi constituída de forma regular, com livre iniciativa da pessoa em constituir a pessoa jurídica, não existindo qualquer espécie de obrigação imposta por um terceiro, o contratante; que a pessoa assumiu integralmente os riscos econômicos decorrentes da criação dessa empresa, isto é, os lucros e os prejuízos; e que a pessoa por trás dessa pessoa jurídica era um verdadeiro prestador de serviços, um verdadeiro trabalhador autônomo, agindo com total 
liberdade e autonomia, a Justiça Trabalhista não reconhece como "pejotização", ou seja, como a modalidade denominada por parcela da doutrina de "pejotização" lícita. Entende apenas que havia uma legítima prestação de serviço por meio de uma empresa regularmente constituída para tal fim, com a presença de um trabalhador autônomo ou empresário.

E quando a Justiça do Trabalho constata que por trás da "pejotização" havia um trabalho prestado por pessoa física, com pessoalidade, de maneira não eventual, com onerosidade e subordinação, demonstra que tal relação trata-se de uma verdadeira relação de emprego. Logo, com base no art. 9, da CLT, o Judiciário Trabalhista declara a nulidade da "pejotização", determinando o reconhecimento e o registro do contrato de emprego por parte da empresa contratante, além do pagamento dos direitos trabalhistas correspondentes.

Por fim, cabe ressaltar que a ausência de lei ou a não edição de uma súmula ou OJ Orientação Jurisprudencial - consolidando o entendimento do TST - Tribunal Superior do Trabalho, de certa forma, proporciona liberdade ao empresariado para recorrer a tal prática e utilizá-la conforme seus interesses.

\section{EFEITOS SOCIAIS E JURÍDICOS DELETÉRIOS DA “PEJOTIZAÇÃO”}

A prática da contratação de uma pessoa jurídica prestadora de serviços personalíssimos acaba tendo o menor custo direto para a empresa contratante, pois como o contrato é interempresarial não gera direitos trabalhistas e recolhimento previdenciário para o tomador de serviços.

Da análise das jurisprudências pode-se observar que a "pejotização" vem se tornando uma imposição do empresariado, tanto para a contratação inicial como também para a manutenção do posto de trabalho, quando o trabalhador é obrigado a rescindir seu contrato de emprego para ser recontratado como "pejota", sem que haja qualquer alteração da sua função.

Assim, diante da imposição feita pelo contratante/empregador à pessoa não resta outra opção além de obter um número de CNPJ - Cadastro Nacional da Pessoa Jurídica - e um bloco de notas fiscais para conseguir lugar no mercado de trabalho ou se manter nele em locais em que o CPF - Cadastro de Pessoa Física - não é mais aceito, fornecendo seu endereço de residência, mas na prática a "pejota" funciona onde se encontra o corpo do trabalhador.

Todavia, conforme análise das jurisprudências, a Justiça do Trabalho tem demonstrado que a "pejotização" é uma prática fraudulenta, usada para camuflar a relação de emprego. Essa 
prática fraudulenta, portanto, acaba irradiando efeitos para além do Judiciário com reflexos sociais, econômicos e políticos.

Os efeitos da “pejotização" são sentidos em todas as áreas da vida comum, diante da fragilidade da seguridade social com seu enfraquecimento econômico, já que a fraude afeta a todos os contribuintes do INSS - Instituto Nacional do Seguro Social, pois é o total arrecadado de todos que será repartido para quem necessita usufruir dos benefícios.

Ademais, as relações de trabalho se tornam precárias e o meio ambiente do trabalho também acaba prejudicado, com riscos à integridade física e à saúde do trabalhador.

Para o trabalhador "pejotizado" acarreta precarização ou perda de direitos trabalhistas, pois não há a incidência destes, representando para o trabalhador não mais a ocupação de uma relação de emprego protegida. Assim, o trabalhador não irá dispor de: pagamento de salário, de décimo terceiro salário e do salário-família; recolhimento do FGTS - Fundo de Garantia por Tempo de Serviço; remuneração do trabalho noturno superior ao diurno; jornada de trabalho não superior às $8 \mathrm{~h}$ (oito) diárias ou $44 \mathrm{~h}$ (quarenta e quatro) semanais; repouso semanal remunerado; remuneração do trabalho extraordinário; gozo de férias anuais remuneradas, com o acréscimo de um terço sobre o salário normal; licença à gestante; licença-paternidade; adicional de remuneração para as atividades penosas, insalubres ou perigosas; seguro contra acidente de trabalho; relação de emprego protegido contra a despedida arbitrária ou sem justa causa; seguro-desemprego; aviso prévio proporcional ao tempo de serviço; redução dos riscos inerente ao trabalho; aposentadoria; dentre outros.

Portanto, o trabalhador envolvido na fraude fica excluído de qualquer proteção trabalhista, inclusive à relativa ao meio ambiente de trabalho sadio. Deste modo, traz consigo insegurança à pessoa que labora em tais condições, pois esta não detém nenhuma garantia. Conforme Castel a proteção social é um elemento necessário que confere segurança ao trabalhador. ${ }^{18}$

Nesse sentido, quando o trabalhador não se insere em um contrato assalariado, este deixa de obter um conjunto de direitos sociais trabalhistas, que engloba desde a sua subsistência diária como também possibilitaria a subvenção extratrabalho como doenças, acidentes, aposentadoria, além da participação na vida social, ao viabilizar acesso à habitação, ao consumo, ao lazer e à construção de uma identidade social. ${ }^{19}$ Conforme Paugam o emprego

${ }^{18}$ CASTEL, Robert. As metamorfoses da questão social. 10. ed. Petrópolis/RJ: Vozes, 2012.
${ }^{19}$ CASTEL, Robert. As metamorfoses da questão social. 10. ed. Petrópolis/RJ: Vozes, 2012. 
insere o trabalhador na lógica protetora do Estado, assim além de definir os direitos sociais também se configura em um dos fundamentos da identidade social. ${ }^{20}$

Além disso, não apenas a classe trabalhadora perde com a "pejotização", pois tal uso também causa concorrência desleal com as empresas que atuam na legalidade e que assumem os riscos inerentes à sua atividade econômica. A empresa que faz uso da "pejotização" aumenta arbitrariamente seus lucros usando de meios escusos, como a sonegação de impostos e o não pagamento de direitos trabalhistas.

A “pejotização" também contribui para o processo de dualização salarial praticado no interior das empresas e de dualização do mercado de trabalho com trabalhadores dentro da empresa executando as mesmas funções, porém com valores remuneratórios diferenciados. 0 trabalhador "pejotizado" também não dispõe da possibilidade de ascensão funcional na empresa que presta serviço.

Ademais, a "pejotização" contribui também para o processo de fragmentação da solidariedade de classe, já que não há a construção de identidade coletiva, pois inexiste sindicato. E por não serem trabalhadores sindicalizados os “pejotas" não irão dispor de acordos ou convenções coletivas que melhorem suas condições de trabalho.

E, ainda, para ter direito a seguridade social o trabalhador "pejotizado" deverá conscientizar-se de que ele mesmo necessitará efetuar a arrecadação das contribuições previdenciárias. Além de que, o valor do encargo social será arcado integralmente por esse, não havendo pagamento de parcela do encargo social por parte do empregador, como ocorre nos casos do contrato regular de trabalho assalariado. No contrato de emprego são descontados $8 \%$ do salário do empregado e o empregador arca até o limite de 12\% (doze) para completar a contribuição previdenciária de $20 \%$ (vinte) sobre a folha de pagamento.

Nesse contexto, o trabalhador poderá enfrentar situações sérias como, por exemplo, não terá direito ao afastamento remunerado no caso de acidente ou de problema de saúde decorrentes do trabalho caso não tenha se responsabilizado em efetuar as contribuições para a Previdência Social.

20 PAUGAM, Serge. O enfraquecimento e a ruptura dos vínculos sociais: uma dimensão essencial do processo de desqualificação social. In: SAWAIA, B (org.) As artimanhas da exclusão: análise psicossocial e ética da desigualdade social. 2. ed. Petrópolis: Vozes, 2001. 
Esses são os principais efeitos sociais, econômicos, políticos e jurídicos deletérios causados pela "pejotização" que foram extraídos da análise das jurisprudências trabalhista e que também são apontados pela doutrina.

\section{EFEITOS SOBRE O CONTRATO DE EMPREGO E O SUJEITO DE DIREITO EMPREGADO}

O Direito do Trabalho foi construído no Brasil para conferir proteção ao trabalhador detentor de um contrato de emprego formal assalariado. Para tanto foi criado um conjunto de regras que regulamentavam e ainda regulamentam a relação de emprego e que conferem ao trabalhador empregado uma gama de direitos sociais trabalhistas, propiciando a este a subsistência diária e a subvenção extratrabalho, além da construção de uma identidade individual e coletiva.

Em que pese no Brasil não haver se efetivado o que Castel $^{21}$ chamou de sociedade salarial, ou seja, aquele tipo de arranjo social caracterizado pelo emprego homogêneo e estável que se configurou na França a partir dos anos de 1950, baseado em uma nova relação salarial que não se resumia apenas à retribuição pontual de uma tarefa, mas que também conferia aos trabalhadores direitos, possibilitava a subvenção extratrabalho e a participação na vida social, a relação de emprego no Brasil passou a ser fomentada pelo Estado atingindo níveis de crescimento entre as décadas de 1930 a 1980.

Assim, embora a relação de emprego jamais tenha sido hegemônica no Brasil, pois enquanto na França o emprego homogêneo e estável abrangia, em 1975, mais de 82\% da população ativa, o que possibilitou falar em sociedade salarial, no caso do Brasil esse tipo de trabalho apenas atingiu mais da metade da PEA- População Economicamente Ativa - com tendências de aumento até o final dos anos de 1970. ${ }^{22}$ Ademais, ao lado da relação de emprego no Brasil sempre houve a presença de outras formas de ocupação que atuavam à margem da legislação social e protetiva como, por exemplo, o assalariamento sem registro e o trabalhador por conta própria.

\footnotetext{
${ }^{21}$ CASTEL, Robert. As metamorfoses da questão social. 10. ed. Petrópolis/RJ: Vozes, 2012.

22 LEITE, Marcia de Paula. 0 trabalho e suas reconfigurações: conceitos e realidade. In: 0 trabalho reconfigurado: ensaios sobre o Brasil e México. Organização de Marcia de Paula Leite e Angela Maria Carneiro Araújo. São Paulo: Annablume; Fapesp, 2009, p. 70.
} 
Portanto, no Brasil a proteção social e o conjunto de direitos trabalhistas estão atrelados à relação de emprego, relação de trabalho na qual figuram em um dos polos o empregador, definido na $\mathrm{CLT}$ no art. $2^{\circ}$, e no outro o empregado, definido no art. $3^{\circ}$, perfectibilizada no contrato de trabalho, na modalidade emprego, o qual deve ser reconhecido na Carteira de Trabalho e Previdência Social - CTPS do trabalhador empregado.

No entanto, quando há a constituição de uma pessoa jurídica por parte do trabalhador este não irá mais ser contratado através de um contrato de trabalho, na modalidade emprego, por meio da assinatura da sua CTPS - Carteira de Trabalho e Previdência Social, mas sim através de um contrato civil, na modalidade prestação de serviços, concretizado entre a empresa contratante e a pessoa jurídica do trabalhador, no qual figura o número de CNPJ - Cadastro Nacional da Pessoa Jurídica - de cada empresa.

Logo, como na "pejotização" há a utilização de um contrato de prestação de serviços, regulamentado pelo Direito Civil, no lugar do contrato de emprego, esta acaba contribuindo para desconstruir o contrato de emprego e também descaracterizar o sujeito de direito empregado, enfraquecendo, assim, a relação de emprego.

O trabalhador "pejotizado" sob o "véu” da formalidade da pessoa jurídica é transformado em prestador de serviços, trabalhador autônomo ou empresário, sendo alterada sua personalidade jurídica. Assim, o empregado transformado em “pejota” não é mais identificado pelo seu número de CPF-Cadastro de Pessoa Física, como pessoa física, natural, ou pela sua CTPS - Carteira de Trabalho e Previdência Social, como trabalhador empregado, mas através de seu CNPJ - Cadastro Nacional da Pessoa Jurídica, da sua ficta identidade jurídica.

Esse trabalhador perde as proteções decorrentes do contrato de emprego e da sua condição de sujeito de direito, não sendo mais abrigado pelo Direito do Trabalho. Modo que, diante de um contrato de prestação de serviços de natureza cível qualquer controvérsia será discutida na Justiça Civil e não na Justiça do Trabalho, sendo apenas discutidas na jurisdição civil as cláusulas do contrato de prestação de serviços, preponderando à paridade entre os litigantes, inexistindo garantias e direitos sociais trabalhistas.

Portanto, ao desconstruir o contrato de emprego e também descaracterizar o sujeito de direito empregado este não irá mais ter a proteção da justiça laboral. Conforme Supiot ${ }^{23} \mathrm{o}$ contrato de trabalho não é apenas fundamento do Direito do Trabalho, mas também constitui o

${ }^{23}$ SUPIOT, Alain. Critique du droit du travail. 2. édition. France: Quadrige/Puf, 2011. 
assalariado como sujeito de direito possibilitando a este um quadro jurídico de ação dentro e fora da empresa, além de civilizar o poder patronal. ${ }^{24}$

Além disso, esse processo de desconstrução e descaracterização também contribui para o enfraquecimento da relação de emprego e o consequente avanço de outras modalidades de ocupação que não possuem o mesmo grau de proteção legal ou que estão desprovidas de qualquer proteção, favorecendo a construção de um mercado de trabalho de frágeis contornos, no qual há o predomínio de relações de trabalho que fomentam a insegurança e a incerteza.

\section{CONCLUSÃO}

No Brasil a proteção do Direito do Trabalho volta-se para a relação de emprego. Um contrato de trabalho que teve suas origens na locação de serviços do Direito Civil e que se afastou desse ramo com a construção de um sistema normativo social, destinado a organizar as classes sociais, distribuindo poder e renda na sociedade, no qual prevalece à preocupação com a questão socioeconômica.

A relação de emprego foi, então, fomentada pelo Estado atingindo níveis de crescimento entre as décadas de 1930 a 1980, embora jamais tenha sido hegemônica no país, pois sempre conviveu lado a lado com outras relações de trabalho não regulamentadas pelo Direito do Trabalho.

Um novo cenário se forma no mercado de trabalho brasileiro a partir dos anos de 1980 e se intensifica nos anos de 1990 com o avanço da globalização, do neoliberalismo, da reestruturação produtiva. O Direito do Trabalho passa a ser afetado por fenômenos políticos, econômicos e sociais. Um novo regime de acumulação do capital, uma nova organização da produção e do trabalho e uma nova racionalidade do trabalho se instaura do país, fazendo com que contratos de trabalho de contornos mais flexíveis, como os processos de externalização, a terceirização e a “pejotização”, passem a ganhar cada vez mais espaço no cenário nacional.

Frente a esse contexto este artigo adotou como principal objetivo apresentar e analisar o fenômeno da "pejotização" e suas principais consequências geradas nas relações de trabalho, nas relações sociais e nas relações humanas.

\footnotetext{
${ }^{24}$ Livre tradução dos autores.
} 
A “pejotização" pode ser compreendida como uma modalidade de externalização dos serviços, na qual para que haja a contratação ou a manutenção do posto de trabalho a empresa contratante exige do trabalhador, pessoa física, que este constituía uma pessoa jurídica. Desta forma, o trabalhador irá prestar os serviços na respectiva empresa mediante um contrato de prestação de serviços de natureza civil realizado entre a empresa contratante e a pessoa jurídica do trabalhador, sem que haja a incidência de qualquer direito trabalhista.

Inicialmente tal modalidade de contratação era identificada por contratação entre empresas e interposição de empresas. Depois passou também a ser denominada de empresa do “eu sozinho”, “pejutização” e, ainda, “PJs”. No entanto, com a sua prática reiterada tal fenômeno passou a ser nominado pelos juristas e doutrinadores trabalhistas brasileiros de "pejotização", pois os trabalhadores que constituíam uma pessoa jurídica para prestação de serviços estavam sendo caracterizados pela abreviação PJ - “pejota”, portanto, da subjetivação da sigla PJ criou-se o neologismo “pejotização”.

Essa modalidade de externalização dos serviços produz consequências sociais e jurídicas deletérias com reflexos de ordem social, econômica, política e jurídica. Pode-se dizer, então, que a “pejotização”, usada para mascarar a relação de emprego, acarreta a precarização de direitos trabalhistas, pois não há o reconhecimento destes, o que faz como que o trabalhador seja excluído de qualquer proteção trabalhista, inclusive da relativa ao meio ambiente de trabalho sadio; interfere na construção da identidade social do trabalhador; fragiliza a seguridade social, pois há o enfraquecimento econômico da Previdência Social, afetando a todos os contribuintes do INSS - Instituto Nacional da Seguridade Social; e provoca a concorrência desleal com as empresas que atuam na legalidade e que assumem os riscos inerentes à sua atividade econômica.

Além disso, desconstrói o contrato de emprego e descaracteriza o sujeito de direito empregado, uma vez que utiliza um contrato de prestação de serviço, regulamentado pelo Direito Civil, no lugar do contrato de emprego. Deste modo, transforma o trabalhador em prestador de serviço, trabalhador autônomo ou MEI - Microempreendedor Individual, empresário com a formalidade da pessoa jurídica. Esse trabalhador não receberá mais os direitos da relação de emprego e a proteção dela decorrente, não sendo mais abrigado pelo Direito do Trabalho, mas sim pelo Direito Civil, seara que prevalece a paridade entre os contratantes e são discutidos apenas as cláusulas do contrato de prestação de serviços.

Ademais, outros problemas também decorrem da "pejotização" tais como: contribui para o processo de dualização salarial e do mercado de trabalho com trabalhadores dentro da 
empresa executando as mesmas funções e recebendo valores diferenciados; o trabalhador “pejotizado" não dispõe da possibilidade de ascensão funcional na empresa em que presta serviços, pois não é detentor de um contrato de emprego; corrobora para o processo de fragmentação da solidariedade de classe; e o trabalhador “pejotizado" deverá se responsabilizar pelas suas contribuições previdenciárias.

Há doutrinadores trabalhistas que defendem a "pejotização" como uma relação de trabalho lícita, estando esta amparada pela Lei n 11.196/2005. Todavia, para a Justiça do Trabalho e parcela majoritária da doutrina trabalhista a “pejotização" é uma prática fraudulenta. Para tais só existe tal fenômeno quando há a transformação da pessoa física em pessoa jurídica para fraudar a legislação trabalhista, previdenciária e fiscal, com o mascaramento da relação de emprego. Consequentemente, reconhecem a "pejotização" como uma relação de trabalho ilícita, que faz uso de um contrato de trabalho sob a aparência de um contrato civil para camuflar a relação de emprego. 0 que faz com que o trabalhador seja transformado em prestador de serviço para que não haja a incidência de direitos trabalhistas. $E$ quando a Justiça do Trabalho verifica que existe uma empresa regularmente constituída com a prestação de serviços executada por um verdadeiro trabalhador autônomo não denomina de "pejotização", apenas de que naquele caso existe uma regular contratação entre empresas nos moldes no Código Civil.

No entanto, ainda não existe uma lei de cunho trabalhista que regulamente a “pejotização" como relação de trabalho. Então, por enquanto, os casos sobre "pejotização” discutidos em âmbito judicial trabalhista vêm sendo resolvidos caso a caso, baseados no contexto de prova produzido, no convencimento e na compreensão desse fenômeno e dos elementos ligados a ele, a relação de trabalho autônomo e de emprego, pelo magistrado trabalhista. Assim, quando há o reconhecimento da fraude, anula-se a "pejotização" e se reconhece a relação de emprego, e quando se constata que há a regular contratação entre empresas, reconhece-se a presença do trabalhador autônomo.

Entretanto, a inexistência de uma lei ou de um entendimento consolidado pelo Tribunal Superior do Trabalho - TST, por meio de uma súmula ou OJ - Orientação Jurisprudencial - que regulamente ou que proíba a prática da "pejotização" traz certa insegurança jurídica, pois casos idênticos podem ser decididos de forma diversa, podendo ser o trabalhador enquadrado como empregado ou autônomo e o empregador podendo a qualquer tempo ser condenado com um passivo trabalhista, fiscal e previdenciário. 


\section{REFERÊNCIAS}

BRASIL. Lei $n^{\circ} 11.196$, de 21 de novembro de 2005. Institui o regime especial de tributação para a plataforma de exportação de serviços de tecnologia da informação - REPES, o regime Especial de aquisição de bens de capital para empresas exportadoras - RECAP e o programa de inclusão digital; dispõe sobre incentivos fiscais para a inovação tecnológica; e dá outras providências. . In: Diário Oficial da República Federativa do Brasil, Brasília, DF, 21 nov. 2005. Disponível em: <http://www.planalto.gov.br/ccivil_03/_ato2004-2006/2005/lei/l11196.htm>. Acesso em: 15 jan. 2015.

. Tribunal Regional do Trabalho ( $5^{\mathrm{a}}$ Região/BH). Acórdão de decisão que negou provimento a preliminar de nulidade de sentença por ausência de completa prestação jurisdicional e, no mérito, concedeu provimento parcial ao recurso do reclamado quanto à prescrição do FGTS, e também provimento parcial ao recurso do reclamante enquadrando-o na categoria de bancário. Recurso ordinário $n^{\circ} 0049200-11.2004 .5 .05 .0021$. Jeferson Malta de Andrade e Banco HSBC. Relator: Desembargadora Maria Adna Aguiar. 19 de novembro de 2009. Disponível em:

<http://www.trt5.jus.br/jurisprudencia/modelo/AcordaoConsultaBlob.asp?v_id=173584>. Acesso em: 12 mar. 2015.

CARELLI, Rodrigo de Lacerda. Formas atípicas de trabalho. 2. ed. São Paulo: LTr, 2010.

CASTEL, Robert. As metamorfoses da questão social. 10. ed. Petrópolis/RJ: Vozes, 2012.

NASCIMENTO, Amauri Mascaro. Curso de direito do trabalho. 26. ed. São Paulo: Saraiva, 2011.

LEITE, Marcia de Paula. 0 trabalho e suas reconfigurações: conceitos e realidade. In: 0 trabalho reconfigurado: ensaios sobre o Brasil e México. Organização de Marcia de Paula Leite e Angela Maria Carneiro Araújo. São Paulo: Annablume; Fapesp, 2009.

PAUGAM, Serge. $O$ enfraquecimento e a ruptura dos vínculos sociais: uma dimensão essencial do processo de desqualificação social. In: SAWAIA, B (org.) As artimanhas da exclusão: análise psicossocial e ética da desigualdade social. 2. ed. Petrópolis: Vozes, 2001.

PEREIRA, Leone. Pejotização: o trabalhador como pessoa jurídica. São Paulo: Saraiva, 2013.

RAMOS FILHO, Wilson. Direito capitalista do trabalho: história, mitos e perspectivas no Brasil. São Paulo: LTr, 2012. 
REIMANN, Marcos Francisco. Cidadania e contratos atípicos de trabalho: as políticas sociais e o ordenamento do trabalho. Porto Alegre: Fabris, 2002.

ROBORTELLA, Luiz Carlos Amorim. O novo conceito de proteção no direito do trabalho. Temas do Direito do Trabalho e Seguridade Social: homenagem ao professor Cássio Mesquita Barros. São Paulo: LTr, 2013.

SUPIOT, Alain. Critique du droit du travail. 2. édition. France: Quadrige/Puf, 2011.

THÉBAUD-MONY, Annie e DRUCK, Graça. Terceirização: a erosão dos direitos dos trabalhadores na França e no Brasil. In: A perda da razão social do trabalho: terceirização e precarização. São Paulo: Boitempo, 2007.

Recebido em: 27/10/2015 / Revisões requeridas em: 08/12/2015 / Aprovado em: 16/12/2015 